\title{
Frequency and precision of feedback and the adaptive process of learning a dual motor task
}

CDD. 20.ed. 152.3

\begin{abstract}
This work investigated the effects of frequency and precision of feedback on the learning of a dual-motor task. One hundred and twenty adults were randomly assigned to six groups of different knowledge of results (KR), frequency $(100 \%, 66 \%$ or $33 \%$ ) and precision (specific or general) levels. In the stabilization phase, participants performed the dual task (combination of linear positioning and manual force control) with the provision of KR. Ten non-KR adaptation trials were performed for the same task, but with the introduction of an electromagnetic opposite traction force. The analysis showed a significant main effect for frequency of KR. The participants who received KR in $66 \%$ of the stabilization trials showed superior adaptation performance than those who received $100 \%$ or $33 \%$. This finding reinforces that there is an optimal level of information, neither too high nor too low, for motor learning to be effective.
\end{abstract}

UnITERMS: Knowledge of results; Feedback; Motor learning; Motor skill; Adaptation; Dual motor task.

\section{Introduction}

Feedback has been considered a fundamental component of the motor learning process (MAGILL, 2007; SCHMidT \& LeE, 2011; SCHMidT \& WrisberG, 2008). During and after the execution of a movement, the learner normally receives two types of feedback about the performance, intrinsic and augmented. Intrinsic feedback is information that comes from the sensory system and augmented feedback comes from an external source. This external information can be provided by either a teacher or researcher and may focus on the outcome (knowledge of performance - KR) or the technique (knowledge of performance - KP).

By the time closed-loop (ADAMS, 1971) and schema (SCHMIDT, 1975) theories were proposed, the main rule when providing KR was "more is always better" to the formation of cognitive structures (traits and schemas, respectively). These theories have triggered several upcoming studies on KR, especially regarding its schedule (frequency), precision and temporal locus. On the whole, the findings indicate that learning was optimized when KR was integral, that is, frequent, accurate and immediate. However, Salmoni, Schmidt and Walter (1984) detected that most of these studies did not use no-KR transfer tests to tear temporary effects of practice (acquisition), apart from permanent learning effects (KR withdrawal). Since then, an experimental design of $\mathrm{KR}$ in acquisition followed by no-KR in transfer was consolidated on the grounds that when $\mathrm{KR}$ is withdrawn on transfer tests, the temporary acquisition effects dissipate and, as a result, learning can be inferred. The paper of SALMONI, SCHMIDT and Walter (1984) can be considered a milestone in the motor learning field because it sparked a flurry of studies (for reviews, see ADAMS, 1987; Swinnen, 1996; Wulf \& Shea, 2004; Wulf, Shea \& LeWTHWAITE, 2009) which not only reexamined classical KR factors (i.e., precision, schedules, temporal locus, interpolation of activities during intervals), but also investigated new $\mathrm{KR}$ variables (i.e., erroneous, bandwidth, and self-controlled). To date, the examination of KR still remains strong and the findings indicate that integral KR is only effective in very special conditions, for example, on initial stages of learning complex motor skills (GUADAGNOLI \& LeE, 2004; ShEA \& Wulf, 2005). Briefly, there seems 
to be a U-inverted tendency according to which either too much or too little $\mathrm{KR}$ is detrimental to learning.

Being able to transfer what was learned to a different, more complex situation (i.e., test, game, audition) has been considered a fundamental goal of most learning contexts. In most formal tests, games or auditions, the performer does not receive any external information on the performance. Although frequent KR guides the learner to the correct motor response during practice, providing $\mathrm{KR}$ often might hinder the capability of the learner adapting by him/ herself. In other words, frequent KR makes a learner dependent on the information provided to such an extent that performance actually suffers when $\mathrm{KR}$ is removed (guidance hypothesis SALMONI, SCHMIDT and WaLTER, 1984). Also, despite guiding the learner to the correct motor response, frequent KR entails detailed adjustments to the movement, preventing the capability of adapting to new situations (instability or maladaptive short-term corrections hypothesis - SCHMIDT, 1991).

The capability of the learner adapting to a more complex situation is the central assumption of a theoretical framework called "adaptive process in motor skill acquisition" (APMSA - BARROS \& CORREA, 2006; Choshi, 2000; Correa, Benda, Meira Junior \& Tani, 2003; Correa, Massigli, Barros, Gonçalves, Oliveira \& Tani, 2010; Manoel, Basso, Correa \& Tani, 2002; TANi, 1982, 1989, 1995, 2005; Tani, Meira Junior $\&$ GOMES, 2005). This framework is based upon the assumption that the learner is an open system because he/she exchanges information, energy and matter with the environment (BERTALANFFY, 1968; Ford \& LERNER, 1992; Prigogine \& Stengers, 1984). Throughout practice and feedback inconsistent and incorrect responses are gradually reduced by negative feedback so that the learner achieves functional stabilization. After this stabilization phase, the learner is supposed to apply what was stabilized to new environment demands or new goals. This adaptation phase is commonly

\section{Method}

\section{Participants and experimental groups}

One hundred and twenty healthy young adults, 60 men and 60 women, aged $25 \pm 4.5$ years, volunteered to participate in the study. All procedures were approved by the University's ethic committee so that the experiment was conducted after each participant understood and signed an informed consent. Independent variables were KR frequency $(33 \%, 66 \%$, and $100 \%)$ and $\mathrm{KR}$ comprised of breaking down the stability by means of perturbations. Effective learning in this background means coping well with perturbations to achieve higher states of complexity (MARUYAMA, 1963). Hence, the APMSA implies a continuous dynamic process of reaching and disrupting stability. As a result, factors of instability, variability and uncertainty should not be reduced or eliminated (BENDA \& TANI, 2005; TANI, 1995, 2005; TANI, MeIRA JuNIOR \& GOMES, 2005), but considered as key elements that facilitate adaptability. The APMSA main proponents (CHOSHI, 2000; TANI, 1995, 2005) have claimed that traditional models of motor learning (closed-loop and schema theories) are limited to explain motor skill acquisition beyond stabilization of performance. According to these classical theories, motor learning is a process of performance improvement across practice and feedback towards automation, which is thought to be the ultimate milestone of the process. Rather, the adaptive process cycle entail a dynamic process towards growing complexity. Our focus is on enhancing the APMSA body of knowledge by investigating $\mathrm{KR}$ as a source of information which reduces uncertainty to achieve the motor goal. Thus the purpose of the current study is to examine the effects of different levels of frequency and precision of $\mathrm{KR}$ in the adaptive process of learning a dual motor task. Our hypothesis is that integral KR (i.e., specific information provided after every trial) degrades the performance of the adaptation phase because, despite effectively guiding the learner to the correct motor response, too much information prevents adaptability.

In order to accommodate the discussion of our results on the existing literature, we will use the concept of challenge point of learning (GUADAGNOLI \& LEE, 2004), a framework which reconciled counterintuitive findings in motor learning. Briefly, its underlying assumption is that learning is directly related to the level of challenge imposed by a practice or feedback condition.

precision [(specific (error magnitude + error direction) and general (only error direction)]. The participants were quasi-randomly assigned to one of six groups (20 subjects each group - 10 men and 10 women) as follows: 1) $100 \%$ specific, 2) $100 \%$ general, 3) $66 \%$ specific, 4) $66 \%$ general, 5) $33 \%$ specific, and 6) $33 \%$ general. It is worth noting that the use of six experimental groups reinforces the idea of an interaction between frequency and precision of $\mathrm{KR}$. 


\section{Apparatus and task}

Custom Electromagnetic Apparatus of Linear Positioning with Dynamometry was developed (MEIRA Junior, Tani, Chabu, Ferraz \& Cardoso, 2004). To accomplish the experimental task, which consisted of movement force (MF) and movement distance (MD), each participant was blindfolded in a standing position and required to grasp the dynamometer lever and move it sideways with an abduction of the shoulder from left to right (FIGURE 1). At the same time, the participant was required to apply force to the dynamometer. The task was performed with the non-preferred hand; a self-report measure of handedness was used (COREN, 1993). The distance goal was $35 \mathrm{~cm}$ and the force goal was $20 \%$ of the maximum force (at the beginning of the experiment, the maximum force was measured). All participants were told to maintain the same force along the entire path. Every trial was performed at the same initial position, with the lever located in front of the chest. No restrictions were imposed on the time to perform the task.

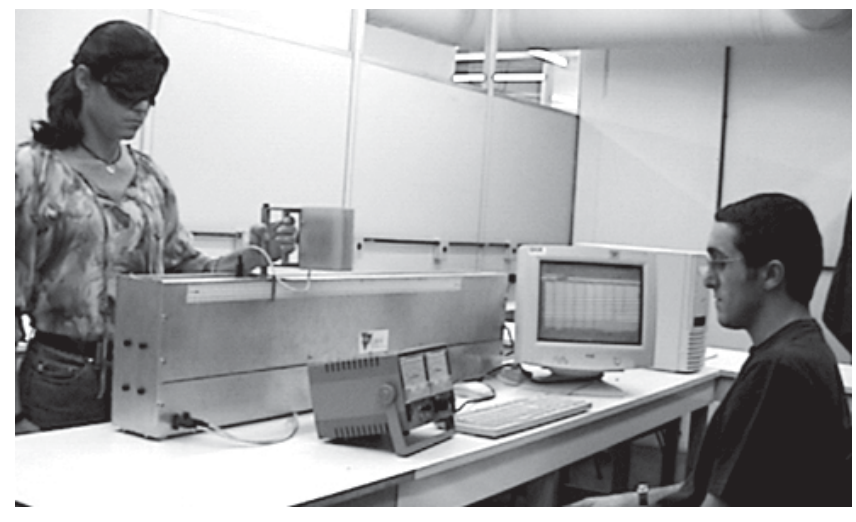

FIGURE 1- Experimental environment.

\section{Procedure}

The experiment was comprised of two experimental phases: stabilization and adaptation. In the first phase, the criterion chosen to infer the functional stabilization was to perform the movement twice in a row within an error bandwidth of one unit of force and distance from the $21^{\text {st }}$ to the $59^{\text {th }}$ trial and within an error bandwidth of two units of force and distance from the $60^{\text {th }}$ to the $99^{\text {th }}$ trial. A minimum of 20 and a maximum of 100 trials were respected. When a learner starts practicing a new skill he/she carries previous experience on movements that positively or negatively affect the current performance. This was the reason why we did not arbitrarily define a fixed amount of stabilization trials. Hence, we believe that our criterion is more tailored to the learners' needs according to his/her previous motor experience.

When provided, KR was verbal, terminal and about the error representing the difference between the outcome of the actual and desired response. KR about MF was always given before KR about MD. Pre-KR interval was of $5 s$, while post-KR interval was of 8 s. When KR was not provided, there was a 13 s inter-trial interval. Five minutes after the end of the stabilization phase, the participants performed 10 no-KR adaptation trials with the introduction of a 2 kgf electromagnetic traction force on the opposite direction of the movement.

\section{Data treatment and analyses}

Stabilization data was considered as long as the $20^{\text {th }}$ trial once all participants performed at least 20 trials and there were no significant changes on means and standard deviations from the $20^{\text {th }}$ stabilization trial onwards. The dependent variable was the absolute error (the difference between the actual performance on each trial and the goal). Data was organized in blocks of five trials. Stabilization data was analyzed with a 3 (Frequency [100\%, 66\%, $33 \%$ ] x 2 (Precision [specific, general] x 4 (Block [E1, E2, E3, E4] analysis of variance with repeated measures on Block. In the adaptation phase, it was used a 3 (Frequency [100\%, 66\%, 33\%] X 2 (Precision [specific, general] x 2 (Block [A1, A2]) analysis of variance with repeated measures on Block. When appropriate, F-ratios involving repeated measures factors were reported with the Greenhouse-Geisser df adjustment. Partial etasquared values $\left(\eta^{2}\right)$ were also reported to indicate effect sizes for significant results. Follow-up testing was conducted using Bonferroni post hoc procedures. For all analyses, alpha was set at 0.05 . 


\section{Results}

\section{Stabilization phase}

Distance (MD)

The analysis showed a significant effect for Block, $\mathrm{F}(1.78,205.88)=100.7\left(\mathrm{p}<0.0001, \eta^{2}=0.47\right)$. In Block 1, the errors were higher than in Blocks 2, 3 and 4. Also, there were more errors in Block 2 than in Blocks 3 and 4.

\section{Force (MF)}

A significant effect for Block was detected, $\mathrm{F}(2.51$, 285.6 $)=62.74\left(\mathrm{p}<0.0001, \eta^{2}=0.36\right)$. In Block 1 , errors were higher than in Blocks 2, 3 and 4. In Block 2, the participants made more errors than Blocks 3 and 4.

\section{Adaptation phase}

Distance (MD)

The analysis indicated a significant effect for the interaction Frequency x Block, F $(2,116)=4.98(\mathrm{p}<$ $\left.0.01, \eta^{2}=0.08\right)$. In the first block, the participants who received KR on $66 \%$ of the stabilization trials made fewer errors than those who received $100 \%$ and $33 \%$ of KR.

\section{Force (MF)}

No significant effects were found, either for main effects or interactions.

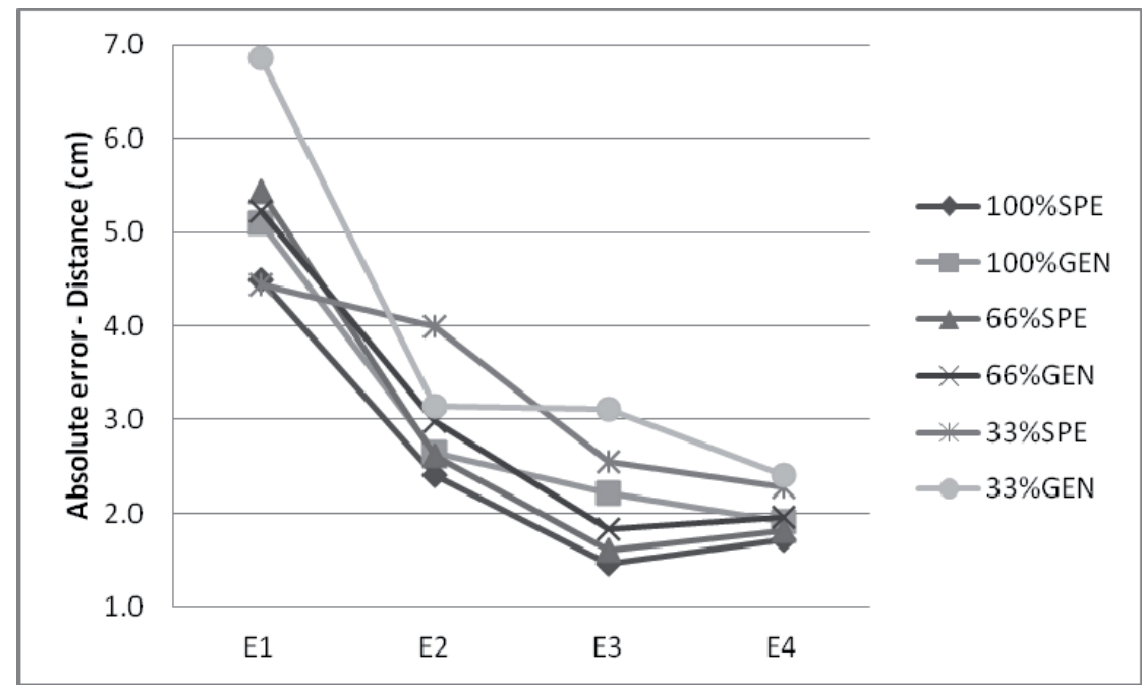

FIGURE 2 - Means of absolute errors on movement distance for KR groups (Stabilization Phase).

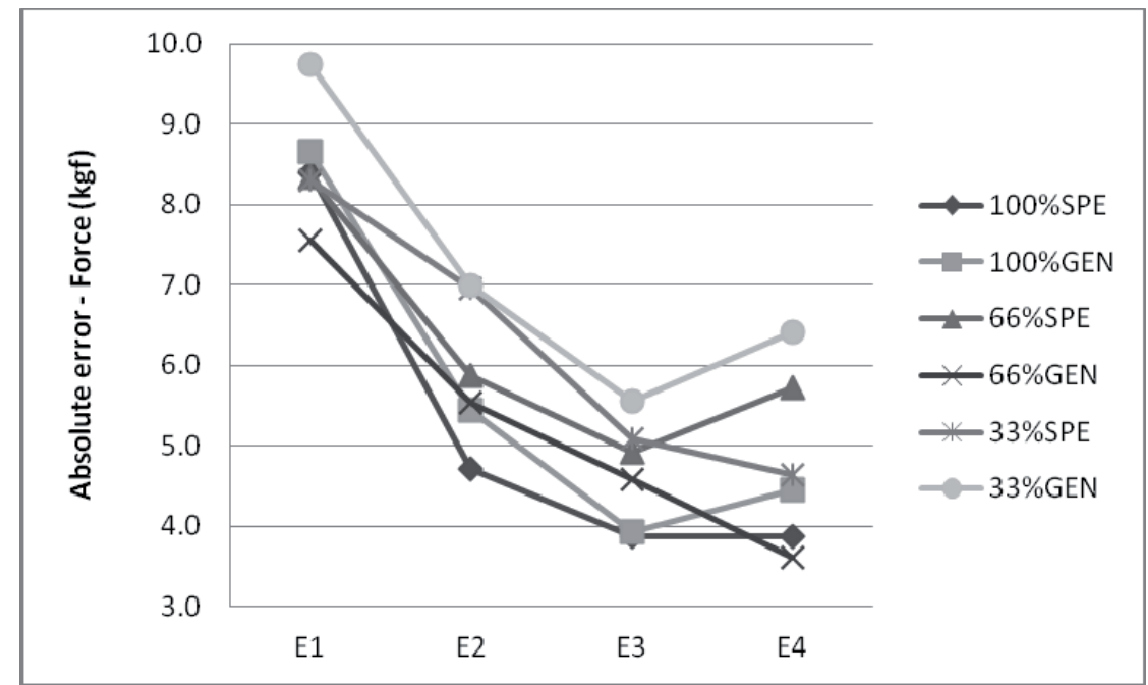

FIGURE 3 - Means of absolute errors on movement force for KR groups (Stabilization Phase). 


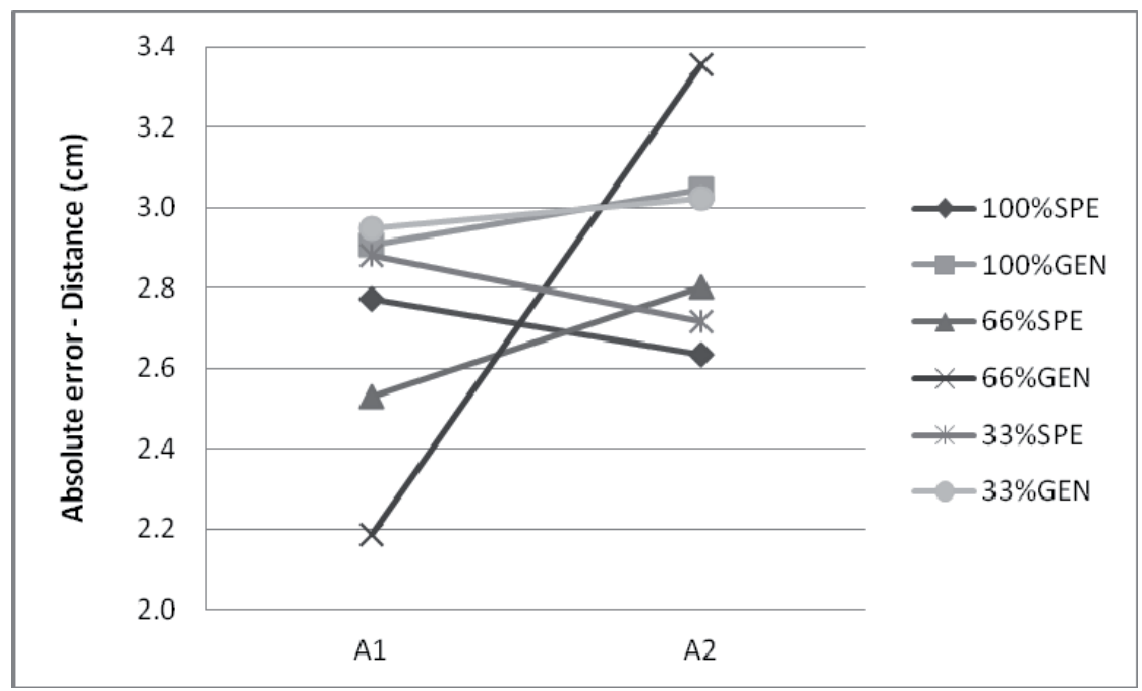

FIGURE 4 - Means of absolute errors on movement distance for KR groups (Adaptation Phase).

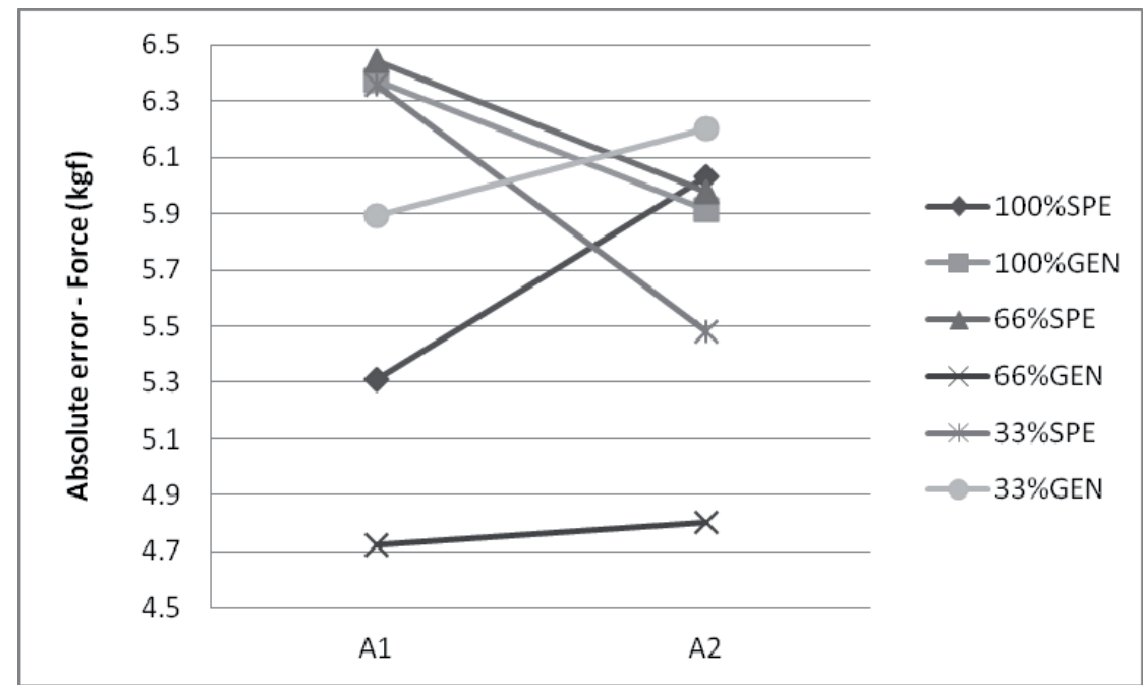

FIGURE 5 - Means of absolute errors on movement force for KR groups (Adaptation Phase).

\section{Discussion}

Although there were no differences among groups in the force requirement of the task, the participants who received $66 \%$ of KR about distance in the practice phase showed enhanced immediate adaptation performance. This finding is in line with the consistent U-inverted pattern for provision of information that has been identified by GuadaGnOli and LeE (2004) and Wulf and SHEA $(2002,2004)$ in the recent motor learning literature. In other words, too much or too little KR during practice degrades the performance in the learning tests. According to the above mentioned authors, there is a relationship between the performance and the characteristics of the task and/or the learner. SHEA and WuLF (2002) advocated that the retention/transfer performance varies as a function of information and task complexity, which is influenced by the environment setting where the task is performed (laboratory or realworld), by the number of acquisition sessions (single or multiple), and by the number of degrees of freedom involved (high or low amount of joints/muscles involved in movement execution). For example, for complex motor skills like a ski-slalom maneuver, KR after every trial $(100 \%)$ during acquisition was more effective in terms of learning than reduced $\mathrm{KR}$. 
GUADAGNOLI and LeE (2004) proposed a challenge point framework $(\mathrm{CPF})$ whose thesis is that information is a challenge to the learner because when it is present there is potential learning. Thus, learning is maximized when a learner faces an optimal level of challenge during practice. In contrast, learning will be compromised if the challenge imposed is either too high or too low. The challenge point created by a learning situation is determined by the functional difficulty of the task, which according to GUADAGNOLI and LeE (2004), results from an interaction between nominal task difficulty, the learner's skill level and the conditions of practice. Given that the nominal difficulty is fixed and is associated with the specific perceptual and motor requirements of the task (juggling three balls has a lower nominal task difficulty than juggling five balls), the higher the nominal task difficulty, the higher the functional task difficulty and, in turn, the higher the challenge point of learning. In the current study, we believe that the skill level of the learner was controlled by means of the stabilization criterion, and, as a result, functional difficulty was similar to all participants. The moderate nominal difficulty of our task can thus be referred to as an explanation to our findings. Even though the task was performed in a laboratory setting with the use of only two degrees of freedom (shoulder and wrist), its dual nature required the learner to process distance and force information simultaneously. A central hypothesis of the CPF is that reduced KR is beneficial to beginners when learning a task with low levels of nominal difficulty, while frequent KR is beneficial to beginners when learning a task with high levels of nominal difficulty. Therefore, it can be inferred that an intermediate schedule of $\mathrm{KR}$, which is neither frequent nor reduced (i.e., 66\%), is beneficial to beginners when learning a task with moderate levels of nominal difficulty.

Based upon the CPF, it seems reasonable to argue that the participants who received KR either always $(100 \%)$ or occasionally $(33 \%)$ had no optimal challenge for learning. Too frequent KR has been reported as detrimental to learning in three aspects: 1 ) it prevents the development of the learner's autonomy because relying on $\mathrm{KR}$ at every trial degrades the exploration of inherent feedback so that the learner bypasses the engagement in active problem-solving strategies (SALMONI, SCHMIDT \& WALTER, 1984); 2) it provokes frequent corrections that lead the learner to focus on detailed adjustments and maladaptive shortterm corrections (SCHMIDT, 1991); 3) it stimulates the inhibition of uncertainty production which is necessary to keep the information flow within the system (TANi, Meira Junior \& Gomes, 2005).

Also, too reduced KR can be detrimental to learning because the lack of a correct augmented source of information in a sequence of trials might weaken the formation of a solid evaluation reference to detect and correct errors. We feel that an intermediate KR frequency (66\%) provided the learners enough room to both compare inherent to augmented feedback after receiving KR and engage in active processes of performance evaluation after no-KR trials (i.e., elaborative encoding by the exploration of inherent feedback).

The lack of differences between general and specific schedules of $\mathrm{KR}$ indicates that different degrees of $\mathrm{KR}$ exactness elicited caused neutral effects in the learning of the dual task. Regardless the content of information that KR provides - either general or specific - it seems that the frequency of $\mathrm{KR}$ is more relevant when precision and frequency of augmented feedback are given together. As detailed information is supposed to be meaningless for beginners (SCHMIDT \& WRISBERG, 2008), another possible explanation for the absence of differences between general and specific $\mathrm{KR}$ is that the participants who received specific KR might have ignored augmented feedback about magnitude of error, having used information about the direction only and thus processing the same content of information processed by the participants who received general $\mathrm{KR}$.

In conclusion, our findings are evidence that an intermediate level of KR frequency can be provided in order to enhance the learning of at least one component while learning a dual motor task.

\section{Resumo}

Frequência e precisão de "feedback" e o processo adaptativo de aprendizagem de uma tarefa motora de dupla demanda

0 presente estudo investigou os efeitos da frequência e precisão de "feedback" na aprendizagem de uma tarefa motora de dupla demanda. Cento e vinte adultos foram aleatoriamente designados a seis grupos de diferentes niveis de frequência (100\%, 66\% ou 33\%) e precisão (específico ou geral) de conhecimento 
de resultados (CR). Na fase de estabilização, a tarefa combinada de posicionamento linear e controle de força manual foi executada com CR. Dez tentativas de adaptação sem CR foram executadas na mesma tarefa, com a introdução de uma força eletromagnética contrária à direção do movimento. $A$ análise indicou efeito significativo no fator "frequência de CR". Aqueles que receberam CR em 66\% das tentativas de estabilização obtiveram desempenho de adaptação superior quando comparados àqueles que receberam 100\% ou 33\% de CR. Esse achado reforça a existência de um nível ótimo de informação, nem muito alto nem muito baixo, para que a aprendizagem seja otimizada.

UnITERMos: Conhecimento de resultados; "Feedback"; Aprendizagem motora; Habilidade motora; Adaptação; Tarefa motora dual.

\section{Resumen}

Frecuencia y necesidad de feedback en el proceso adaptativo de aprendizaje de una tarea motora dual

El presente estudio investigó los efectos de la frecuencia y necesidad de feedback en el aprendizaje de una tarea motora de dupla demanda. 120 adultos fueron aleatoriamente designados a seis grupos de diferentes niveles de frecuencia (100\%,66\% o 33\%) y necesidad (específico o general) de conocimiento de resultados (CR). En la fase de estabilización, la tarea de posicionamiento lineal y control de fuerza manual fue ejecutada con CR. Diez tentativas de adaptación sin CR fueron ejecutadas durante la misma tarea, con la introducción de una fuerza electromagnética contraria a la dirección del movimiento. El análisis indicó efecto significativo en el factor "Frecuencia de CR": aquellos que recibieron CR en 66\% de las tentativas de estabilización obtuvieron desempeño de adaptación superior cuando comparados a aquellos que recibieron 100\% o 33\% de CR. Ese resultado refuerza la existencia de un nivel óptimo de información, ni muy alto ni muy bajo, para que el aprendizaje sea optimizado.

Palabras Clave: Conocimiento de resultados; Feedback; Aprendizaje motora; Habilidad motora; Adaptación; Tarea motora dual.

\section{Referências}

ADAMS, J.A. A closed-loop theory of motor learning. Journal of Motor Behavior, Washington, v.3, p.111-50, 1971. . Historical review and appraisal of research on the learning, retention, and transfer of human motor skills. Psychological Bulletin, Washington, v.101, p.41-74, 1987.

BARROS, J.A.C.; CORREA, U.C. Practice schedule and adaptive process in motor learning: effects of task specificity. Journal of Sport and Exercise Psychology, Champaign, v.28, p.S30, 2006.

BENDA, R.N.; TANI, G. Variabilidade e processo adaptativo na aquisição de habilidades motoras. In: TANI, G. (Ed.). Comportamento motor: aprendizagem e desenvolvimento. Rio de Janeiro: Guanabara Koogan, 2005.

BERTALANFFY, L.V. General systems theory. New York: George Braziller, 1968.

CHOSHI, K. Aprendizagem motora como um problema mal-definido. Revista Paulista de Educação Física, São Paulo, p.16-23, 2000. Suplemento 3.

COREN, S. Measurement of handedness via self-report: the relationship between brief and extended inventories. Perceptual and Motor Skills, Missoula, v.76, p.1035-42, 1993.

CORREA, U.C.; BENDA, R.N.; MEIRA JUNIOR, C.M.; TANI, G. Practice schedule and adaptive process in the acquisition of a manual force control task. Journal of Human Movement Studies, London, v.44, p.121-38, 2003.

CORREA, U.C.; MASSIGLI, M.; BARROS, J.A.C.; GONÇALVES, L.; OLIVEIRA, J.A.; TANI, G. Constant-random practice and the adaptive process in motor learning with varying amounts of constant practice. Perceptual and Motor Skills, Missoula, v.110, p.442-52, 2010.

FORD, D.H.; LERNER, R.M. Developmental systems theory: an introduction approach. Newburypark: Sage, 1992. 
GUADAGNOLI, M.A.; LEE, T.D. Challenge point: a framework for conceptualizing the effects of various practice conditions in motor learning. Journal of Motor Behavior, Washington, v.36, p.212-24, 2004.

MARUYAMA, M. The second cybernetics: deviation-amplifying mutual causal processes. American Scientist, New Haven, v.51, p.164-79, 1963.

MAGILL, R.A. Motor learning: concepts and applications. Boston: McGraw-Hill, 2007.

MANOEL, E.J.; BASSO, L.; CORREA, U.C.; TANI, G. Modularity and hierarchical organization of action programs in the acquisition of graphic skills. Neuroscience Letters, Limerick, v.335, p.83-6, 2002.

MEIRA JUNIOR, C.M.; TANI, G.; CHABU, I.E.; FERRAZ, M.E.; CARDOSO, J.R. Desenvolvimento tecnológico de um aparelho eletromagnético de posicionamento linear com dinamometria para o estudo em aprendizagem e controle motor. Revista Portuguesa de Ciências do Desporto, Porto, v.4, p.155-56, 2004.

PRIGOGINE, I.; STENGERS, I. Order out of chaos: man's new dialog with nature. New York: Bantam, 1984.

SALMONI, A.W.; SCHMIDT, R.A.; WALTER, C.B. Knowledge of results and motor learning: a review and critical reappraisal. Psychological Bulletin, Washington, v.95, p.355-86, 1984.

SHEA, C.H.; WULF, G. Schema theory: critical reappraisal and re-evaluation. Journal of Motor Behavior, Washington, 37, p.85-101, 2005.

SWINNEN, S.P. Information feedback for motor skill learning: a review. In: ZELAZNIK, H.N. (Ed.). Advances in motor learning and control. Champaign: Human Kinetics, p.37-66, 1996.

SCHMIDT, R.A. A schema theory of discrete motor skill learning. Psychological Review, Washington, v.82, p.225-60, 1975.

Motor learning and performance: from principles to practice. Champaign: Human Kinetics, 1991.

SCHMIDT, R.A.; LEE, T. D. Motor control and learning. Champaign: Human Kinetics, 2011.

SCHMIDT R.A.; WRISBERG C.A. Motor learning and performance: a situation-based learning approach. Champaign: Human Kinetics, 2008.

TANI, G. Adaptive process in perceptual-motor skill learning. Unpublished Doctoral Dissertation. Faculty of Education, Hiroshima University (in Japanese), Hiroshima, 1982.

Hierarchical organisation of an action programme and the development of skilled actions. Sheffield: Department of Psychology/University of Sheffield. 1995.

. Variabilidade de resposta e processo adaptativo em aprendizagem motora. Tese (Livre-Docência) - Escola de Educação Física, Universidade de São Paulo, São Paulo, 1989.

(Ed.). Comportamento motor: aprendizagem e desenvolvimento. Rio de Janeiro: Guanabara Koogan, 2005.

TANI, G.; MEIRA JUNIOR, C.M.; GOMES, F.R.F. Frequiência, precisão e localização temporal de conhecimento de resultados e o processo adaptativo na aquisição de uma habilidade motora de controle da força manual. Revista Portuguesa de Ciências do Desporto, Porto, v.5, p.59-68, 2005.

WULF, G.; SHEA, C.H. Principles derived form the study of simple motor skills do not generalize to complex skill learning. Psychonomic Bulletin and Review, Austin, v.9, p.185-211, 2002.

. Understanding the role of augmented feedback: the good, the bad, and the ugly. In: WILLIAMS, A.M.; HODGES, N.J.(Eds.). Skill acquisition in sport: research, theory and practice. New York: Taylor \& Frances/Routledge, 2004. p.121-44. WULF, G.; SHEA, C.H.; LEWTHWAITE, R. Motor skill learning and performance: a review of influential factors. Medical Education, Oxford, v.44, p.75-84, 2009.

\begin{tabular}{|c|c|}
\hline $\begin{array}{r}\text { ENDEREÇO } \\
\text { Cássio Miranda Meira J unior } \\
\text { Escola de Artes, Comunicação e Humanidades - USP } \\
\text { Av. Arlindo Bettio, } 1000 \\
03828-000 \text { - São Paulo - SP - BRASIL } \\
\text { e-mail: cmj@usp.br }\end{array}$ & $\begin{array}{l}\text { Recebido para publicação: 31/ 10/2011 } \\
\text { Revisado: 27/02/2012 } \\
\text { Aceito: 27/ 03/2012 }\end{array}$ \\
\hline
\end{tabular}

